\title{
НЕКИ КАРАКТЕРИСТИЧНИ ПРИМЕРИ КОДА ИЗ БЕТОВЕНОВОГ СТВАРАЛАШТВА
}

\author{
Данијела В. Илић* \\ Универзитет у Нишу, Факултет уметности у Нишу, Република Србија
}

\begin{abstract}
Сажетак
Након опширног истраживања на тему коде у Бетовеновим делима', сматрамо да би овакав рад био од користи, јер су у њему истакнути многи карактеристични примери кода из Бетовеновог стваралаштва, од почетних и кратких, које се пре могу назвати спољашњим проширењима, па до оних које представљају коде целог циклуса, а не само облика у чијем су саставу. Селекција овом приликом није примењена у зависности у оквиру ког формалног обрасца су се јавиле.
\end{abstract}

Кључне речи: завршна група, кода, проширење, резимирање, синтеза

\section{Увод}

Еволуција музичког размишљања у стваралаштву Бетовена (Ludwig van Beethoven) достиже нове и снажне црте које одражавају опште тенденције класицизма у свим сферама. У драми као и у области филозофије, закључивање се све више намеће као важан моменат, јер су ту сконцентрисани елементи који користе заштити једне тезе - уметничке, филозофске или научне. Завршни моменат је у драми врло често праћен епилогом у којем се рекапитулира основна идеја. У једној чврсто изграђеној филозофској тези, тренутак закључивања је пресудан, јер има улогу центра ка којем води цело претходно излагање и развој мисли. Ако у почетном историјском стадијуму класицизма има потчињеније значење, онда се може рећи да у Бетовеновом стваралаштву постоји неопходност његове појаве, што проистиче из сложености „догађаја", од нове линије драмског развоја и изоштрених контраста, који у неким случајевима достижу ниво конфликта.

Д. Илић, „Роля и значение на кодата в логическата организация на музикалната форма в творчеството на Бетховен", магистарски рад, рукопис, 1996, Национална музикална академия „Проф. Панчо Владигеров" София (Бугарска).

danijelailic1@yahoo.com 


\section{Једна од могућих класификација кода у Бетовеновим клавирским сонатама, увертирама и симфонијама}

Формирање коде као резимирајућег, интегришућег тематског дела је процес који је протицао неравномерно у различитим категоријама музичких форми. У раду су анализирани неки примери кода у Бетовеновим клавирским сонатама, увертирама и симфонијама. Класификација кода² која није у зависности од формалног решења аналитичког узорка може се применити на следећи начин:

1. непостојање коде

2. појава спољашњег или унутрашњег проширења које „преузима“ улогу коде

3. коде сачињене из једног одсека

4. развијене коде које имају два или више одсека

5. коде целог циклуса.

Нотни примери описани у раду биће „једни од карактеристичних“ (по мишљењу аутора), из сваке групације наведене у класификацији.

Усложњавање тематско-формалних узајамних односа између елемената у одвојеним стадијумима изградње и повишена улога процесуалности природно воде повећању размера периферног дела форме, где се постепено формира специфичан закључни комплекс средстава. У њему се сакупљају линије различитих сила, што води настајању карактеристичне семантике. Њен дијапазон се показује као врло широк и варира од директних, постулативних позитивних нијанси, па до скривенијих, индиректних одражаја и ретроспекција. У завршним деловима форме Моцарт (Wolfgang Amadeus Mozart) је јасно „уздржанији”, док Бетовен управо у том стадијуму исказује посебан интерес ка ширењу. Пут ка формирању коде води од стварања спољашњих проширења, ка одвајању коде као самосталне и снажно развијене функционалне зоне, са посебно важним значајем резимирајућег фактора. У њој се појављују различите линије кретања тематских сила и елемената, који достижу свој врхунац у процесуалној изградњи форме.

У раним Бетовеновим сонатама, односно у готово свим његовим раним делима, не постоји кода као самостална функционална сфера. Најчешће њену функцију преузимају проширења (нпр. у Менуету из Симфоније бр. 1). Чак и у сонатној форми из раног периода кода недостаје као самостални део, при чему завршна група експозиције на неки начин преузима функцију коде. Ретко се јавља реализација коде након каденце, или са појавом главне теме која је праћена материјалом с краја завршне групе, али са појачаном каденцом у сазвучју завршног дела (Холопова, 2006, 334-335). Тако се појављују контуре будуће коде (у овом формалном решењу у микроплану су назначени стадијуми којих ће бити мање или више у кодама каснијих његових композиција).

Проширење и кода имају заједнички корен, снажну генетску везу, с тим да кода има шире резимирајуће могућности и тематски процеси су у њој са већим радијусом деловања.

Због обима овог рада није могуће поменути друге начине класификација, које се могу видети у горе наведеном раду или у радовима других аутора. 
Занимљиво решење може се видети у првом ставу Сонате за клавир оп. 2, бр. 1. Завршна група у репризи је, по димензијама, структури $(2+2+3)$ и тематском материјалу остала иста, но на хармонском плану није. Наиме, осим што је сада у основном тоналитету (еф-молу), у свом последњем тротакту модулира се у субдоминантни бе-мол, након чега се понавља само двотакт, сада у Ас-дуру и враћа се у тонични еф-мол, где даје само субмотив претходног мотива, у сврху каденцирајућег процеса.

Пример 1 (Л. ван Бетовен; Соната за клавир оп. 2, бр. 1, први став, 146-152т)

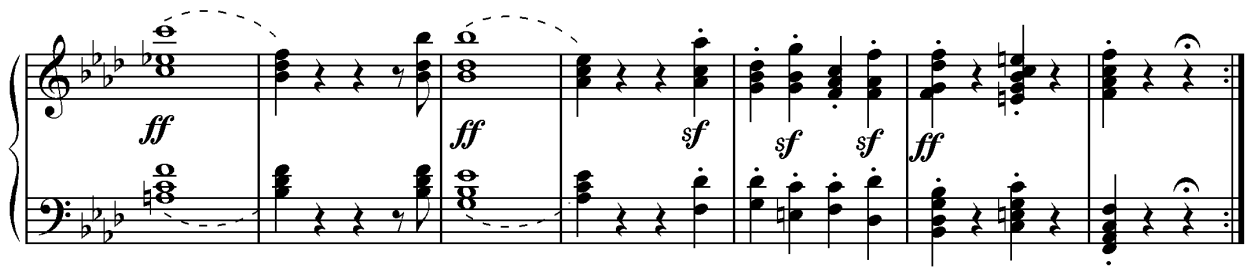

Слична ситуација примећује се већ у првом ставу Сонате за клавир оп. 7, где идеја о будућој коди и њеној стабилизирајућој улози поприма јасније облике (313-362т). Бетовен овде показује један карактеристичан пример изградње коде. Њен почетак уведен је без видљиве синтаксичке границе, резимира основне тематске материјале, али без истог редоследа као у експозицији и репризи, већ их „ређа” другачијим редоследом чиме развија скривене везе међу њима. Добијена естетска стабилност и компактност не би била иста да је ова кода била другачија.

У трећем ставу Сонате за клавир оп. 10, бр. 3, Менует садржи спољашње проширење од једанаест тактова (Пример 2). Оно је, не само спољашњи, периферни фактор, већ неодвојив део опште динамике који стабилизује развој просте троделне форме, супротставља се нестабилности у репризи и ствара стабилност неопходну за крај. У њему се примећује и наглашавање два важна елемента: најснажнија, лирско-секстетска интонација од почетка периода, која је овде дата виолончелском текстуром, и скривене хроматике чији је хармонски ход узет с краја репризе. Осим тога, смештање секстетске лирске интонације у ниски виолончелски регистар има и други важан смисао: њено просторно приближавање и интеграција са тематиком средњег дела. Одсуствовање коде компензује се проширењем и његова улога локалног фактора стабилизације расте, тако да, на неки начин, преузима улогу и значај коде.

Пример 2 (Л. ван Бетовен; Соната за клавир оп. 10, бр. 3, трећи став, Менует, 43-54т)

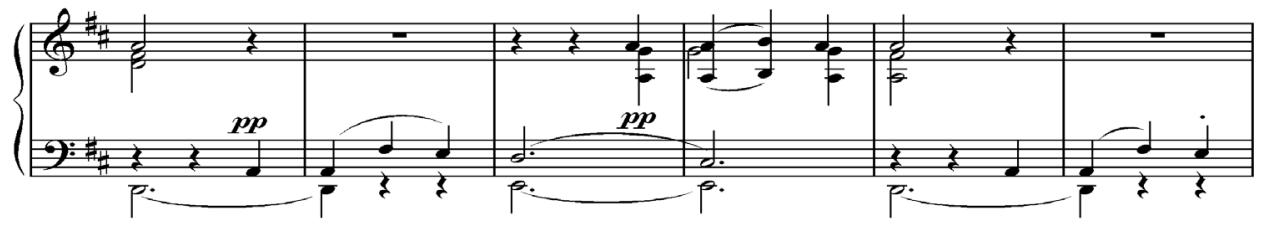




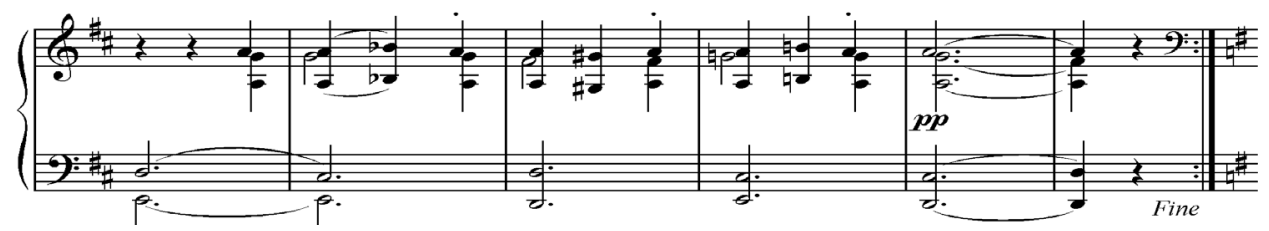

Присуство спољашњег проширења уз трећи део сложене троделне форме среће се и код неких обимније разрађених менуета Моцартових симфонија, где кода одсуствује као самостални функционално-аутономни део. Такав случај среће се у трећем ставу Симфоније бр. 40, у ком је проширење део периода.

У првом ставу Сонате за клавир оп. 2, бр. 3 завршна група је проширена, чиме добија улогу коде. У постојећа два одсека који су дати у завршној групи експозиције, уметнуто је јако много тематског материјала. Други одсек завршне групе (218-232т) доноси тематски материјал из централног одсека развојног дела, трећи (233-248т) материјал прве теме, док је четврти (249-257т) већ је постојао у завршној групи експозиције, али овом приликом појачаном унисоном фактуром.

Пример 3 (Л. ван Бетовен; Соната за клавир оп. 2, бр. 3, први став, 211-257т)
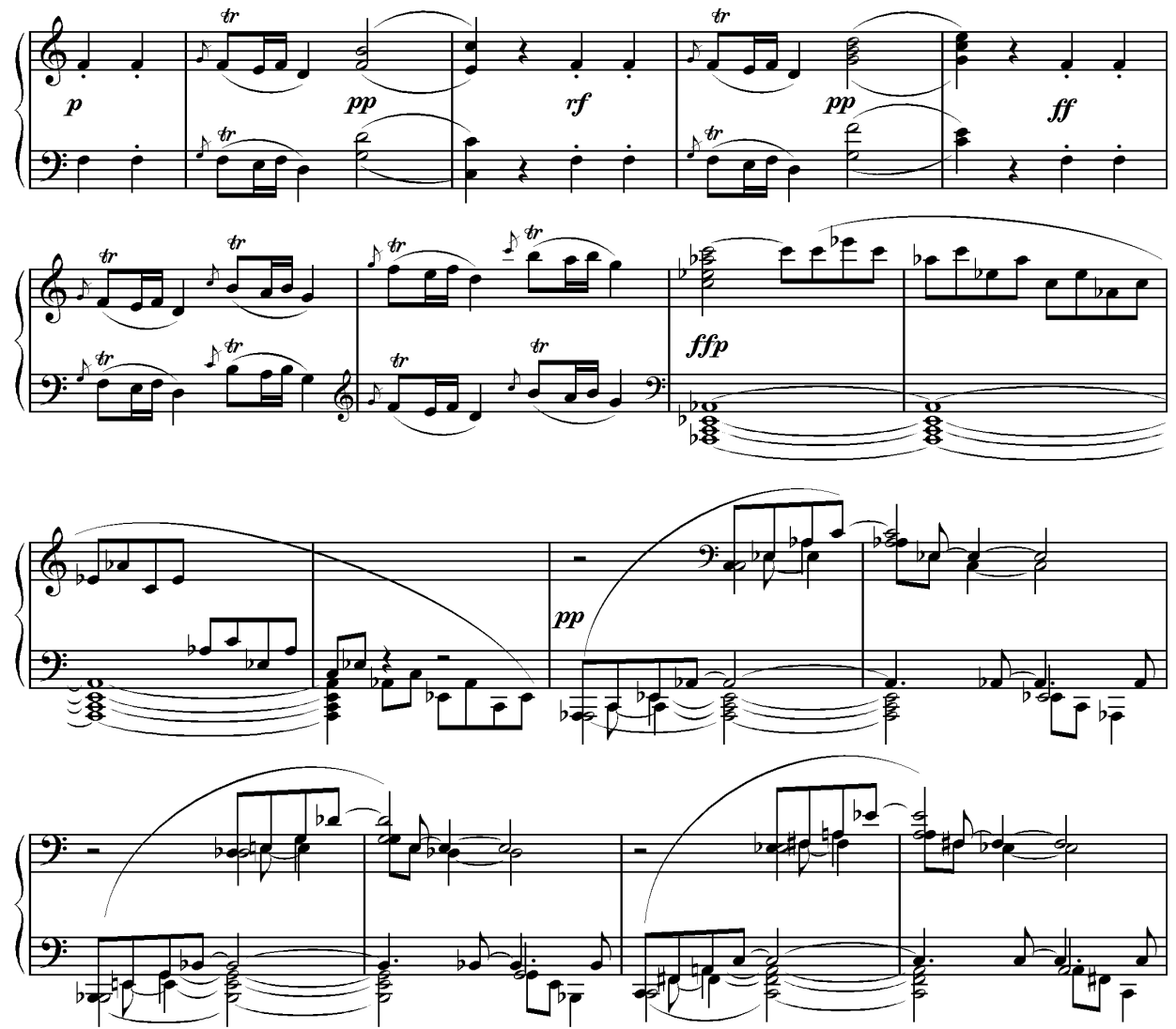

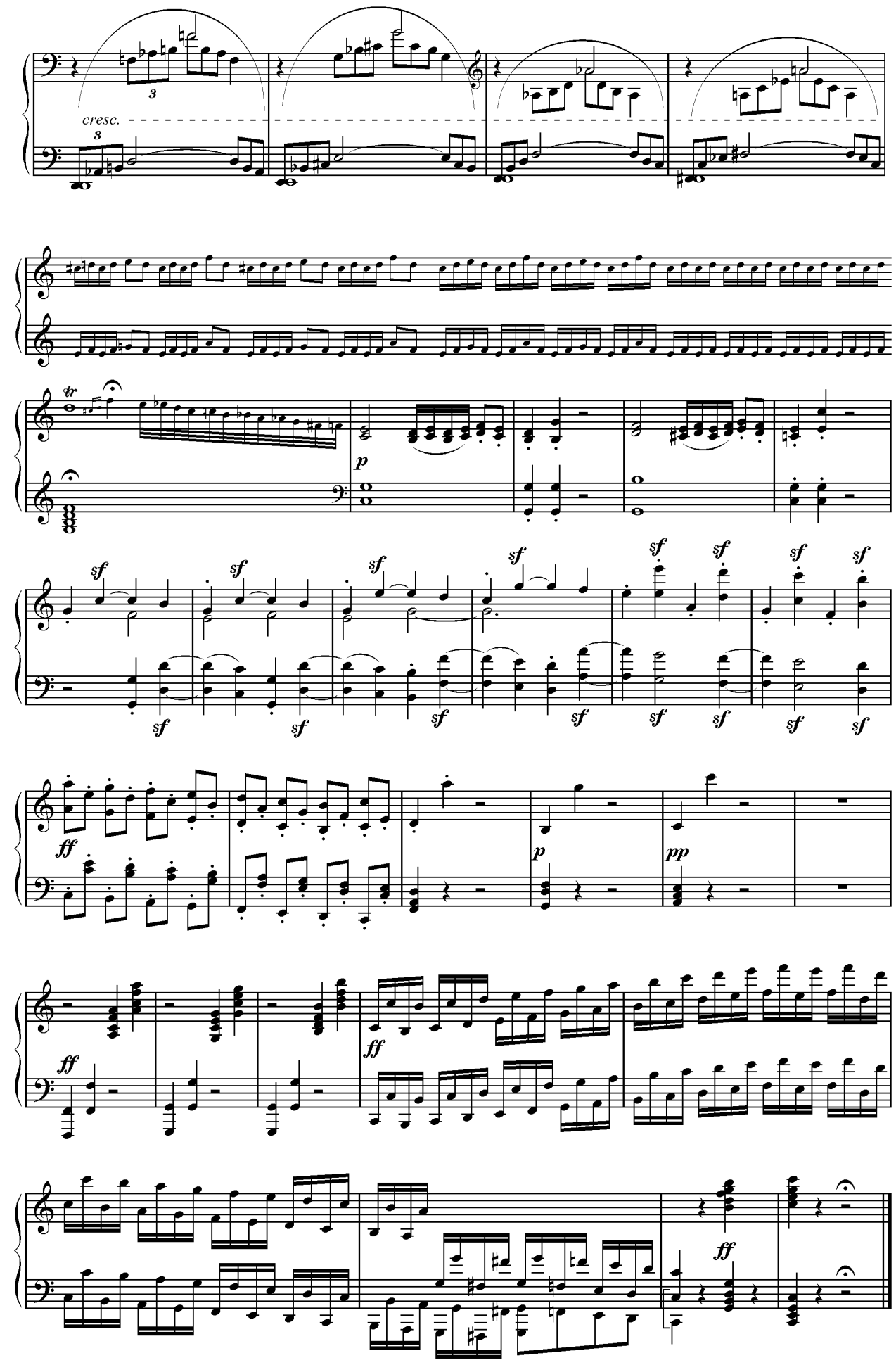
Пример 3 јасно показује рађање и и стварање контура етапа/фаза будућих кода. Још је један разлог важности овог примера: појава тематског материјала прве теме у трећем одсеку завршне групе. Стварање оваквог поступка имаће за резултат појаву тематског материјала или дела теме, понекад чак и целе прве теме у коди. На тај начин, тематско заокружење става бива јаче. Слушно, а и аналитички, овај поступак доприноси приближавању сонатног облика и ронда.

У другом ставу Сонате за клавир оп. 10, бр. 1 појављује се развијена кода. Она садржи појаву главне теме трећи пут (91.т), чиме нагиње ка појави рондо-принципа. Овакво „кодовско” спровођење главне теме додатно развија варирање материјала и његову већу „распеваност”, што издалека наговештава романтичарске идеје. Интересантна је и унутрашња структура коде, која поседује три дела, где сваки од њих има различит степен стабилности, тако да су најстабилнији последњи тактови који садрже дуготрајно и стабилно присуство тоничне функције, али ипак са кретањем надоле и поступним смањивањем броја гласова.

Код Бетовена „зрела“ кода није само један „post scriptum” или епилог, већ логичан део у којем је сконцентрисан један од најважнијих момената у општој логици формалне изградње: моменат синтезе који интегрише у јединство тематске елементе. Пут ка коди води од постепено нарастајуће улоге спољашњих проширења, и код простих и код сложених форми које садрже проширења на крају. Проширење као фактор развитка форме има заједнички корен са кодом и представља неопходан моменат наставка и завршетка енергетских ресурса тематског материјала, који излазе из његових синтаксичких граница и теже да створе нова поља.

у Сонати оп. 53, оп. 57, увертири Кориолан, првом ставу Симфоније бр. 5 и увертири Егмонт, развој у репризи излази из оквира тоналног јединства тема, тако да је разрешење основног конфликта пренесено и налази се у коди (Стојанов, 1995, 159). Класична структурна решења била су недовољна за огромни потенцијал сила које делују у зрелим, драматичним Бетовеновим делима, што је разлог развоја који излази из традиционалних класичних оквира и тражи нове изразе. Он користи начине закључивања као што су: проширења периода, простих форми или сложене троделне форме на месту где се један заокружен део завршава (крај првог или средишњег дела сложене троделне форме). Проширења која имају улогу кодете јављају се и у варијационој форми (Соната оп. 14, бр. 2, други став, или други део проширења ка првој теми двотемских варијација у другом ставу Симфоније бр. 5)

Оваквом виду проширења врло су блиске коде неких ранијих Бетовенових варијационих циклуса. У Сонати за виолину и клавир оп. 12, бр. 1, спори део уместо коде садржи широко развијено проширење. У првом ставу Бетовенове Сонате за клавир оп. 26 , кода доноси микродетаље, тј. елементе, који су узети из теме и индиректно из неких варијација (Способин, 1980, 153-157). 
Овај случај стоји на граници између једног широко развијеног спољашњег проширења и коде, и индикативан је за блискост између те две јединице. Кода целог варијацијског циклуса у првом ставу Сонате за клавир оп. 26, укључује се у општу логику конструкције као важан детаљ који учествује у симетричном распореду фаза и у изградњи варијација.

Пример 4 (Л. ван Бетовен; Соната за клавир оп. 26, први став, 204-219т)
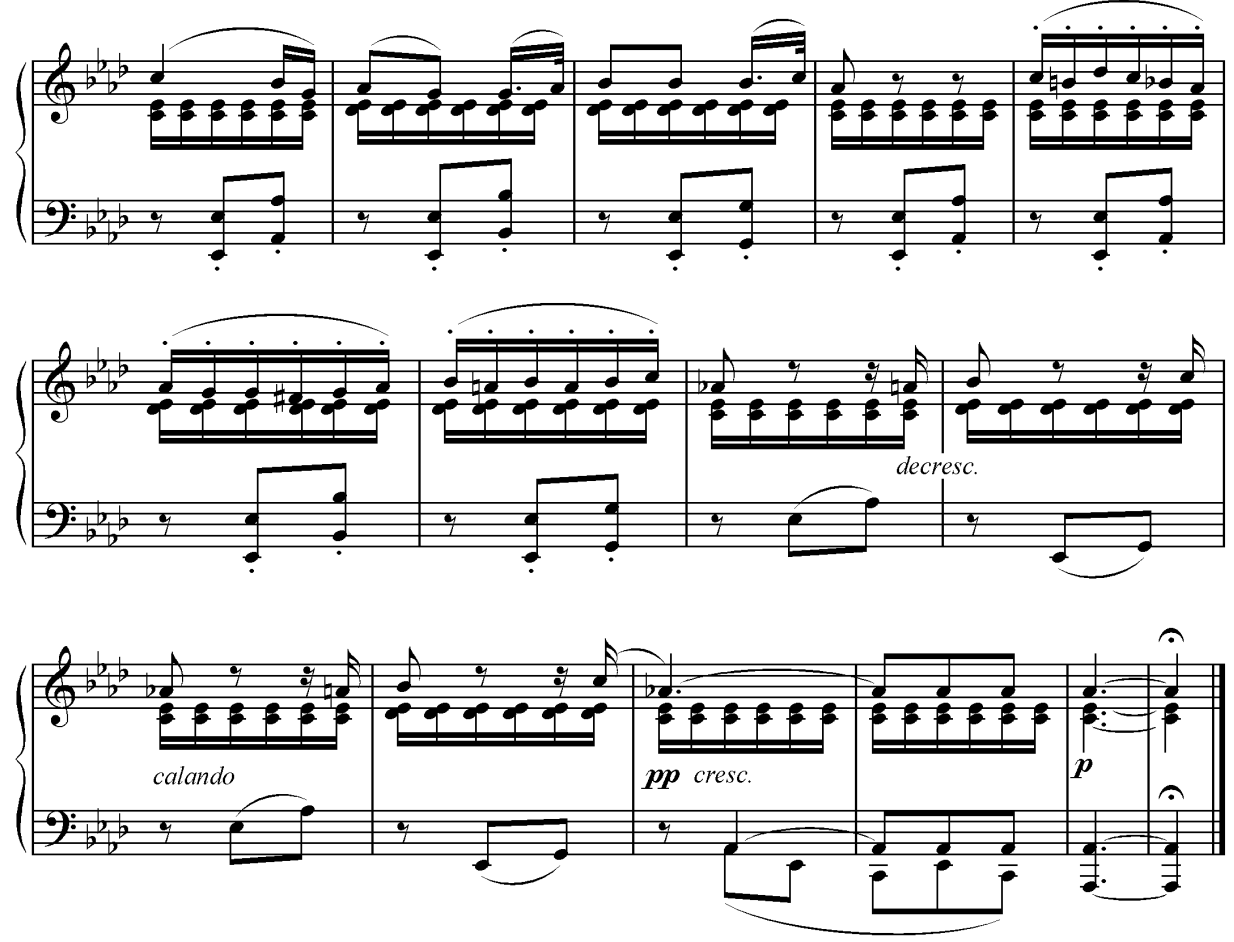

У другом ставу Бетовенове Сонате за клавир оп. 14, бр. 1, кода се гради од тематског материјала дела Б сложене троделне форме, као и његове тоналне сфере, која се постепено „разлева” и уступа место главном тоналитету, који се налази на спољашњим деловима целе форме:

Табела 1: Соната за клавир оп. 14, бр. 1, други став

\begin{tabular}{cccc}
\hline А & Б & А & Кода \\
\hline а-б-а1 + проширење & а-б & а-б-а1 & тематски материјал дела Б \\
\hline е-мол & Це-дур & е-мол & Це-дур - е-мол \\
\hline
\end{tabular}

Временски параметри интеграцијског процеса елемената у коди у неким случајевима могу да буду крајње лаконски. У Скерцу из Бетовенове Симфоније бр. 7, која је написана у виду сложене троделне, тј. петоделне форме (А-Б-А-Б-А), 
кода одражава и уопштава, у изузетно кратком временском одсеку, два основна елемента: почетак дела Б, са његовим необично изразитим фонским ефектом и идентичним каденцирајућим акордима из првог дела. Кроз те целине, које резимирају у максимално смањеним временским пропорцијама обе основне тематске сфере, добија се брз „обухват“ тематике целог става, при чему обе налазе заједнички језик. Њихова интеграција остварена је у два правца:

1. Хоризонтална синтеза у низу „Б - А”

2. Тонска доследност, чиме се зближавају два контрастна дела који су носиоци изразите фоничности. На тај начин се између њих „провлачи" обједињујући мост који их спаја у јединство:

Табела 2: Симфонија бр. 7, Скерцо

\begin{tabular}{cc}
\hline Б & $A$ \\
\hline Де-дур - де-мол & Еф-дур \\
\hline
\end{tabular}

Аналогни тип коде са изузетно добро организованим временским параметрима видимо и у Скерцу Бетовенове Симфоније бр. 9 (Способин, 1980, 220). Овде контраст између тематских сфера припада другачијем типу и у њима се дирекно осликавају обе главне, магистралне линије тематизма сонатног циклуса: драматизам, и с њим повезана интензивна полифонична нит првог става (адекватно првом делу, скерца са акцентом на тоналитет де-мол), и отворенија осећајност песме која крчи пут ка „Оди радости”, тоналитетом светлијим по колориту (де-мол), формирајући „светло” поље у центру скерца. У коди су ова два елемента смештена у релативно кратак временски одсек:

Табела 3: Симфонија бр. 9, Скерцо

Б

A

Материјал почетка Трија

Комплекс каденцирајућих унисоних тонова на Д и Т

Интересантно је и то да је са̂м Бетовен означио границу где почиње кода. У њу је укључио и проширење првог дела скерца (ретроспективно и трећег). Још је интересантније укључивање „рама” у коду, где је материјал из Трија окружен унисоним акцентима каденцирајућег процеса на Д и Т.

Овај Скерцо писан је у виду врло занимљивог тродела, који се ретко среће у класицизму:

Табела 4: Симфонија бр. 9, Скерцо

A Б $A$ 
Линеарно остварена, хоризонтална синтеза, са делимично скраћеним временским пропорцијама синтетизираних елемената, има свој прототип у врло развијеним кодама Бетовеновог симфонијског стваралаштва. у првом ставу Симфоније бр. 5, кода је изграђена у неколико етапа ${ }^{3}$, где је тек у последњој кључни моменат (део где су теза и антитеза постављене једна за другом). ${ }^{4}$ Такође је занимљиво то што у другој половини користи два елемента:

1. Ритмички моменат из прве теме који наглашава његову јамбску природу и

2. Комплекс типичних каденцирајућих средстава где се Д и Т функција понављају.

У Бетовеновом стваралаштву сложена троделна форма има широк дијапазон структурних решења са наглашеном тенденцијом ка процесуалности. Она излази из традиционалних оквира. Код Хајдна (Franz Joseph Haydn) и Моцарта је сваки део усмерен на себе и не срећу се случајеви усложеног развитка који стварају неопходност постојања коде (Стојанов, 1995, 158). Бетовен динамизује процесе у сложеној троделној форми, мења традиционалност дајући већу процесуалност деловима и усложњава унутрашње односе међу елементима.

У другом ставу Треће симфоније он динамизује репризу и помоћу полифоне фактуре у њој ствара повишену процесуалност. Услед свега тога, реприза излази из традиционалних оквира и траје дупло дуже. Висок ниво процесуалности достиже до тада непознате димензије, тако да овај став приближава сонатној форми са динамизујућом репризом. Такви поступци јављају се у његовом опусу из зрелог и последњег периода стваралаштва. Може се установити да је однос ка репризи у овом Посмртном маршу донео нови приступ репризама, што мења профил целе форме. Моћно, активацијско деловање полифоније захтева и адекватно супротно деловање које води ка стабилизацији. Појава опширне коде је моменат рађања новог начина изградње и развитка интересантних процеса. Њихова разноврсност и широк радијус деловања је узрок растуће улоге резимирања и синтезе, као једне од најјачих логичких страна Бетовеновог размишљања. Кода је место у ком реалан израз налазе скривене и дубоке везе међу елементима, крајња тачка процесуалне изградње која доводи развој догађаја до логичног завршетка. Један од типичних видова рада са тематским материјалом је избор и селекција оних елемената који имају велики значај за општу драматургију, ново сједињење елемената и из других делова форме (Бобровски, 2010, 93-102). У овој сложеној троделној форми кода доноси елементе и спољашњих делова и трија. Они су укључени у нови, синтетизујући ком-

\footnotetext{
Аналогни начин изградње види се и у краткој коди из другог става Симфоније бр. 5 Д. Шостаковича (Дмитрий Дмитриевич Шостакович), где он линеарно приближава валцерску тему из Трија, за којом даје војнички унисон елемената из Скерца.

4 Погледати тактове: 483-490 (теза) и 491-502 (антитеза).
} 
плекс, који има висок ниво стабилности, која се не губи након последњих каденцирајућих комплекса. У оваквој ситуацији кода постаје кључни део, где поступно наступа смирење, успостављање нарушеног уравнотежења у репризи, која се као таква врло ретко среће и у сложеној троделној форми и из касних историјских етапа. Ова кода има различите фазе. Прва фаза дубоко залази у субдоминантну област. Почетак је у Ас-дуру, но поступно се јавља наполитанска сфера Дес-дура. Она је одраз опште линије фугата из репризе, која ставља акцент на субдоминантну област. Модел фугата је у еф-молу и до краја потенцира тачку ослонца стављену на тон фа. Субдоминантна област је симптом који показује дејство скривеног сонатног језгра и њено ново, још дубље потврђивање у коди има јак психолошки смисао (у старогрчкој теорији, фригијска област била је носилац драматизма и трагедије). Наполитанско субдоминантно скретање у репризи је моменат који је високо тематизован и у коме постоје и елементи из Трија, но они су сада јако промењени и „приближени“ новом окружењу. Други стадијум коде доноси најизраженије детаље из средине првог дела. Тиме што су варирани и „пребачени” у дур, овај део се приближава колориту Трија. Овакав заокружен део реткост је у грађи кода. На његовом крају се јављају последњи наполитански тонални импулси, али овде доста покривено, јер је у основи тонични ослонац. Посебно је интересантна последња фаза ове коде, где се јавља тема Посмртног марша, но сада у преображеном и занимљивом виду. Измењена је на начин који ствара осећај распадања и потпуног стишавања енергије до најниже тачке. У оквиру метро-ритмичког ослонца основног једра, паузе стварају „луфт”, чиме се шири пространство уз успорено кретање материјала.

\section{Закључак}

Бетовенов однос ка структурној логици форме достиже врло висок ниво, који указује на музичко размишљање са перспективом устремљеном ка нашој савремености. Стварајући у зони коде резимирајући део, Бетовен у многим случајевима мења њену тежину и приближава општу логику процесуалности драми. У првом ставу његове Симфоније бр. 5 може се видети да реприза сонатног облика остаје „отворена”, нема ништа друго осим излагања двеју тема у основном тоналитету и реконструкције тоналног плана са минималним променама, без икакве динамизације. Реприза овде не даје одговор на питање која тематска садржина је јача и заузима водећу улогу. Одговор је премештен и налази се у коди где, након паузе, започиње драматична експресија, последњи захват, након чега је друга тема радикално промењена. У њој се појављују црте драматизма, што води ка последњим тактовима који имају карактер категоричног императива, који у први план поставља драматично начело. 
Логички резиме који Бетовен гради у широко развијеним кодама (у сонатама за клавир оп. 53, оп. 57, у првим ставовима симфонија бр. 3 и бр. 5, као и у увертири Кориолан) представља корак напред, и то како из угла опште логике изградње и функционалности музичке форме, тако и тематизма, као и временско-просторних димензија. Настаје закључни моменат у коди, јер она постаје место разоткривања и утврђивања основне идеје. Бетовен то постиже употребљавајући најразличитији семантички потенцијал преко нових, специфичних поступака моделирања тематског материјала. У интересантној панорами појава везаних за тематске процесе у изградњи коде, могу да се донесу неки закључци о новим моментима:

Појава нових, све до коде непоказаних веза међу тематским елементима (са могућим сједињењем на хоризонталном, вертикалном или хоризонталновертикалном плану).

Дистанционо обједињавање тематских елемената из различитих делова форме (типичан пример је кода у првом ставу Симфоније бр. 3, где је део из развојног дела сонатног облика не само поново изложен већ он овде налази „заједнички језик” са основним тематским материјалом и са њим образује ново јединство високог ранга.

Карактеристичан комплекс средстава која успоравају кретање, као и она која доприносе стабилизацији и која имају примат у ставу - држе својеврстан „монопол“ у коди.

Нови, јаки облици логичког размишљања у стваралаштву Бетовена одражавају се на пуноћу његовог виђења целокупних процеса у свим стадијумима развоја форме: од почетних импулса, од основних сила, па до њиховог спровођења у логички завршетак. У том вишеетапном систему, Бетовен у први план ставља улогу уопштавања и синтезе у општу логику изградње коде. У њима се огледа естетска позиција композитора, његов поглед на целокупан процес формирања облика и на узајамне односе стадијума у композиционом плану. Бетовен има такав приступ коди, која, независно од њене величине, има склоност ка постепеном преображају у део који постаје саставни у односу на општу логику изградње. Та тенденција је најчешћа у сонатном облику, где је кода „прешла еволутивни пут” од кратког проширења које „појачава” репризу (нпр. у првом ставу Сонате за клавир оп. 2, бр. 1), па до огромног уопштавајућег дела у ком се налази кључни моменат целог става (нпр. први став Сонате за клавир оп. 53; први и трећи став Сонате за клавир оп. 57; финала симфонија бр. 2, бр. 3 и бр. 5; увертире Кориолан и др.). Преношењем закључног, разрешујућег момента из развојног дела у коду појачава се драматургија целог става и настаје ново распоређивање енергије. За разрешавање таквог сложеног, не само техничког подухвата, већ и естетског задатка, Бетовен пажљиво користи моделирање материјала. Моменат селекције елемената је врло одговоран и превасходно захтева познавање својстава тематског материјала, као и 
унутрашњих сила. На том путу, Бетовен још у раној Сонати за клавир оп. 7 (у првом ставу) показује један карактеристичан пример изградње коде. Њен почетак уведен је без видљиве синтаксичке границе, резимира основне тематске материјале, али без истог редоследа као у експозицији и репризи, већ их „ређа” другачијим редоследом, чиме развија скривене везе међу њима. Добијена естетска стабилност и компактност не би била иста да је ова кода била другачија.

Веома је интересантна скала процеса које овај композитор користи у кодама. Бетовен веома лако употребљава адекватна средства да би успорио или убрзао процесе у коди. Могући су моменти где приближава елементе, подржавајући њихово међусобно деловање линеарном синтезом (нпр. први став Appassionate), но такође и њихово конфронтирање, које смешта у први план, тражећи помоћ од темпа као средства. Такав пример види се у првом ставу Сонате за виолину и клавир оп. 47, где у коди опроштајни Adagio, који доноси судбоносну триолу, прати моћни, последњи део коде, где су трагичне црте дубоко ушле у тематику друге теме, утврђујући централни моменат драме првог става.

Бетовенова естетика показује да је постојање дубоких унутрашњих веза међу елементима, као и употребљавање јаких, изоштрених контраста, у зависности од конкретних уметничких идеја самог композитора.

\section{Литература/References}

Бобровский, Виктор П. 2010. Тематизм как фактор музыкального мышления, Москва: Книжный дОМ „ЛИБРОКОМ"

Холопова, Валентина, Николаевна. 2006. Формы музыкалных произведений,Санкт-Петербург Москва - Краснодар: Московская Государственная Консерватория имени П. И. Чайковского, „Лань"

Способин, Игорь, Владимирович. 1980. Музыкальная форма. Москва: „Мугриз“

Стоянов, Пенчо. 1995. Музикален анализ. София: „Музика“ 
ORIGINAL SCIENTIFIC PAPER

Artical language: Serbian

\title{
THE REVIEW OF THE MOST CHARACTERISTIC CODAS IN BEETHOVEN'S WORKS
}

\author{
Danijela llić \\ University of Niš, Faculty of Arts in Niš, Republic of Serbia
}

\section{Summary}

An extensive research of the coda in Beethoven's compositions has resulted in writing this paper which competently presents numerous examples of the coda typical of Beethoven's opus. The codas depicted range from those early and short ones, which can be described as outer extensions, to those that represent the codas of the complete cycle, not only of the form that contain them. The selection has not been based on the formal pattern in which they occurred.

Key words: final group, coda, extension, summarizing, synthesis.

Datum prijema članka/ Paper received on: 6. 6. 2019.

Datum dostavljanja ispravki rukopisa: Manuscript corrections submitted on: 14. 6. 2019.

Datum konačnog prihvatanja članka za objavljivanje / Paper accepted for publishing on: 17.10. 2019.

(C) 2019 Autor. Objavio Artefact (http://www.artf.ni.ac.rs/index.php/casopis-artefact/).

Ovo je članak otvorenog pristupa i distribuira se u skladu sa Creative Commons licencom (http://creativecommons.org/licenses/by/3.0/rs/).

(c) 2019 The Author. Published by Artefact (http://www.artf.ni.ac.rs/index.php/casopis-artefact/). This article is an open access article distributed under the terms and conditions of the Creative Commons Attribution license (http://creativecommons.org/licenses/by/3.0/rs/).

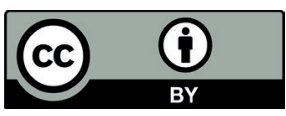

